\title{
ENTOMOLOGY
}

\section{On distribution of Mimela holosericea (Fabricius, 1787) (Insecta, Scarabaeoidea, Scarabaeidae, Rutelinae) in Russia and adjacent territories}

\author{
A.B. Ruchin, ${ }^{1}$ L.V. Egorov ${ }^{1,2}$ \\ 1Joint Directorate of the Mordovia State Nature Reserve and National Park "Smolny", Saransk City, Republic of \\ Mordovia; ${ }^{2}$ Federal Government Funded Institution “Prisurski State Nature Reserve”, Lesnoy Settlement, Cheboksary \\ City, Chuvash Republic, Russian Federation
}

\begin{abstract}
Based on literature analysis and museum collections, the range of Mimela holosericea (Fabricius, 1787) is defined. Outside of Russia, M. holosericea is distributed in Kazakhstan, Mongolia, some northern provinces of China, the Korean peninsula and Japan. Within the Russian Federation, the species is recorded in 30
\end{abstract}

Correspondence: Alexander B. Ruchin, Joint Directorate of the Mordovia State Nature Reserve and National Park «Smolny», Saransk City, Republic of Mordovia, Russian Federation.

E-mail: sasha_ruchin@rambler.ru

Key words: Mimela holosericea, Scarabaeidae, Rutelinae, range, biology.

Acknowledgments: Many thanks to V.G. Bezborodov (Blagoveshchensk), E.A. Belyaev (Vladivostok), S.V. Dedukhin (Izhevsk), I.I. Kabak (St. Petersburg) for information assistance; V.K. Zinchenko (Novosibirsk), A.A. Gusakov (Moscow), A.V. Ivanov (Ekaterinburg) for information on collection materials of SZM ISEA, ZMMU and ZM IPAE respectively; L.A. Akhmetova (St. Petersburg) for help with ZIN collection handling; S.A. Karpeev (Cheboksary), M.E. Smirnov (Ivanovo), R.V. Filimonov (St. Petersburg), A.V. Korshunov (Kemerovo) - for information on materials from private collections.

Contributions: the authors contributed equally.

Conflict of interest: the authors declare no potential conflict of interest.

Funding: none.

Received for publication: 2 March 2018.

Revision received: 13 June 2018.

Accepted for publication: 13 June 2018.

(C) Copyright A.B. Ruchin and L.V. Egorov, 2018

Licensee PAGEPress, Italy

Journal of Entomological and Acarological Research 2018; 50:7390

doi:10.4081/jear.2018.7390

This article is distributed under the terms of the Creative Commons Attribution Noncommercial License (by-nc 4.0) which permits any noncommercial use, distribution, and reproduction in any medium, provided the original author(s) and source are credited. administrative regions (the Far East, Eastern, Western and Southern Siberia, the Urals, Volga River basin and Central Russia). It is most abundant and most frequently recorded at the Far East: the Jewish Autonomous Region, Primorsky Krai, Khabarovsky Krai, Amur and Sakhalin Regions. In the western part of its range - Volga River basin and Central Russia - the species is sporadically distributed, though the number of specimen records here has increased in recent years. The main habitats are sparse pine forests (on glades, roadsides, fringes) and floodplain cenoses.

\section{Introduction}

Melolontha holosericea: Fabricius, 1787: 21. Typical locality «Rossia» [Russia].

Anomala holosericea: Lindeman, 1871: 281; Matsumura, 1911: 119; Esterberg, 1929: 50.

Anomala (Rhombonyx) holosericea: Jacobson, 1900: 3; Semenov, 1904: 114.

Rhombonyx holosericea: Medvedev, 1949: 107; Galkin, 1961: 1039; Stebnicka, 1980: 275; Nikolajev, Pontsagdulam, 1984: 219; Nikolajev, 1987: 188; Kalinina, 1989: 411; Nikitsky et al., 1996: 57; Degma, 1997: 7; Dedukhin, 2003: 10; Bezborodov, 2006: 308; Bezborodov, 2009: 140; Kyzyl-ool, 2013: 84.

Mimela holosericea: Hua, 2002: 174; Kim et al., 2006: 135; Nikitsky, 2009: 51; Bezborodov, Zinchenko, 2010: 45; Park et al., 2010: 20; Shabalin, 2011: 68; Shabalin, Bezborodov, 2012: 265; Bayartogtokh et al., 2012: 213; Bezborodov, 2013a: 136; Bezborodov, 2014: 138; Bezborodov, 2016: 130; Zorn, Bezděk, 2016: 345.

Subfamily Rutelinae consists of more than 200 genera and over 4200 species (Krajčík, 2008). This is a very diverse group, common in most countries of the world. Within Russia there are more than 40 species (Zorn, Bezděk, 2016). Rutelinae have significant biocenotic and economic value (Ruchin, Kurmaeva 2010; Limbourg, 2014; Sarkar et al., 2016). In the adult stage beetles feed on leaves, buds, flowers of plants, i.e. when abundant they considered to be potential pests of cultivated plants and forest vegetation. Larvae of this species are rhizophagus (Medvedev, 1949).

In recent years ranges of many Coleoptera (Abood, Murphy, 
2006; Sekerka, 2007; Kurzawa, 2012) were described in detail. It is particularly interesting in zoogeographical respect that this eastern in the territory of Russia species is penetrating to the west to European part of the region. This article describes present distribution of one such species - Mimela holosericea (Fabricius, 1787).

\section{Materials and Methods}

There were examined entomological collections of the Zoological Institute of Russian Academy of Sciences, Zoological Museum of Moscow State University, Siberian Zoological Museum, Institute of Systematics and Ecology of Animals, Zoological Museum of Institute of Plant and Animal Ecology of Russian Academy of Sciences (Ural Branch).

ZMMU: collection of Zoological Museum of Lomonosov Moscow State University (Moscow, Russia);

ZIN: collection of Zoological Institute of Russian Academy of Sciences (Saint-Petersburg, Russia);

SZM ISEA: collection of Siberian Zoological Museum, Institute of Systematics and Ecology of Animals, Russian Academy of Sciences, Siberian Branch (Novosibirsk, Russia); ZM IPAE: collection of Zoological Museum of Institute of Plant and Animal Ecology Russian Academy of Sciences (Yekaterinburg, Russia).

When materials from collections are mentioned, the exact label content is given in quotes. To prepare the distribution maps (Figure 1) we considered all reliable indication of the species (according to literature - described in section Literature and collections of materials - Material Examined). In Figure 1, numerals indicate regions of the species distribution in Russia (according to the numbering in the list of finds in the region).

Special attention when processing collections is given to the materials from the European part of Russia and the Urals. The examined material is deposited in the collections of ZIN, ZMMU, ZM IPAE, SZM ISEA, Mordovia State Nature Reserve, L.V. Egorov (Cheboksary), S.A. Karpeev (Cheboksary), M.E. Smirnova (Ivanovo), R.V. Filimonov (St. Petersburg) and A.V. Korshunov (Kemerovo).

The nomenclature is given by Zorn, Bezděk (2016). This species is not included in the Fauna Europaea database (2017).

\section{Results}

\section{Distribution outside of Russia}

Kazakhstan, the Irtysh River Valley (Nikolajev, 1987: 188); Northern Kazakhstan (Bezborodov, 2016: 130).

China (Heilongjiang, Jilin, Liaoning, Beijing, Inner Mongolia, Hebei, Shanxi, Henan, Shaanxi, Qinghai) (Hua, 2002: 174; Zorn, Bezděk, 2016: 345); Xinjiang (Hu Hongying, Huang Renxin, 2013: 89); Northern China (Stebnicka, 1980: 275); Northeast China (Kalinina, 1989: 411; Bezborodov, 2013a: 136, 2014: 138; Bezborodov, 2016: 130).

Mongolia (Jacobson, 1900: 3; Stebnicka, 1980: 275; Nikolajev, Pontsagdulam, 1984: 219; Zorn, Bezděk, 2016: 345; Insects of Lazovsky Nature Reserve, 2009: 130; Bayartogtokh et al., 2012: 213; Bezborodov, 2016: 130).

The Korean Peninsula (Stebnicka, 1980: 275; Kalinina, 1989: 411; Kim et al., 2006: 135; Insects of Lazovsky Nature Reserve, 2009: 130; Bayartogtokh et al., 2012: 213; Bezborodov, 2016:

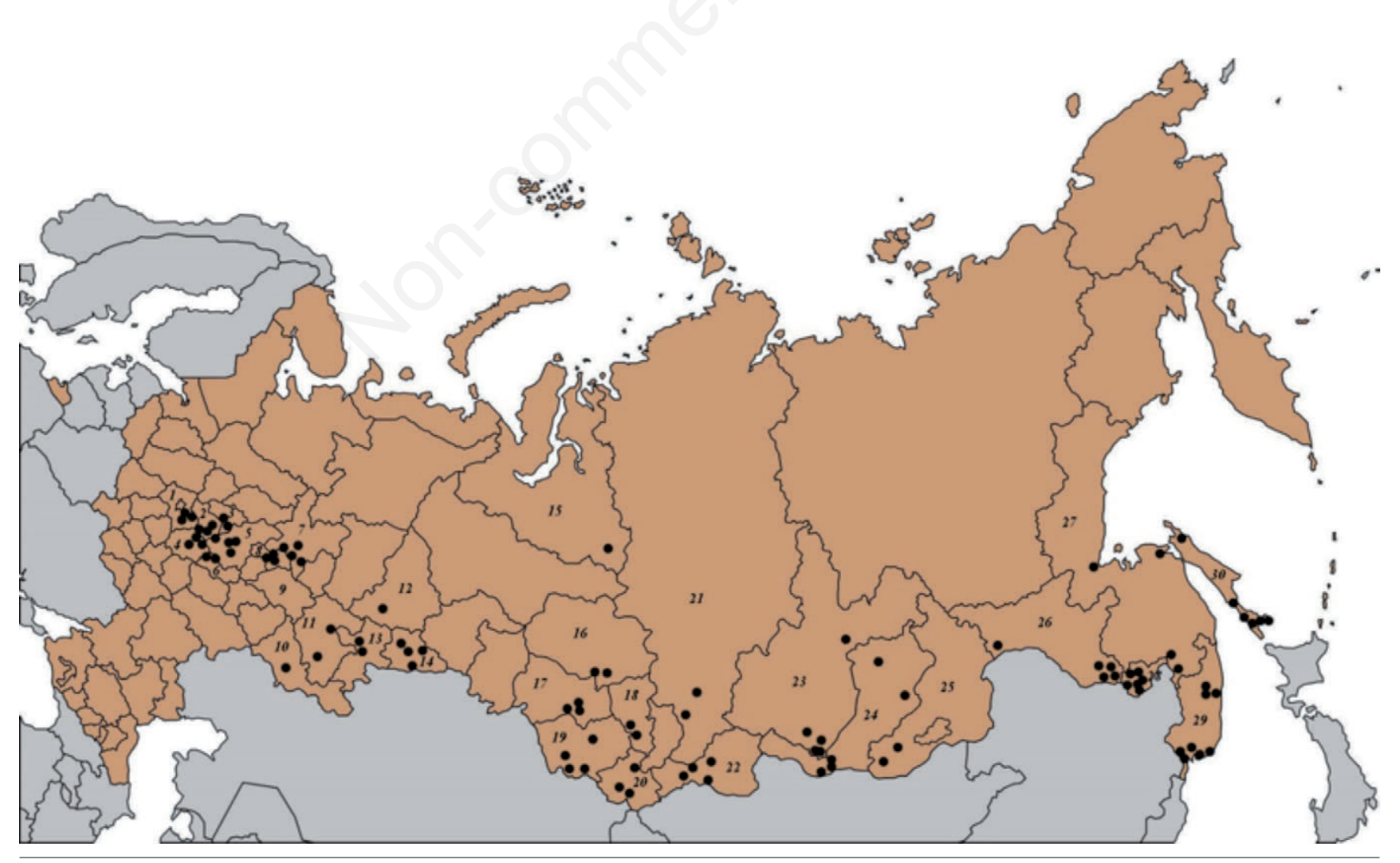

Figure 1. Distribution Map of Mimela holosericea within the Russian Federation (Numbers on the map correspond to the regions). 
130); North Korea (Zorn, Bezděk, 2016: 345); Is. Boleum-do (Park et al., 2010: 20).

Japan (the island of Hokkaido, Kyushu, Honshu, Shikoku) (Ueno et al., 1989: 401; Hua, 2002: 174; Insects of Lazovsky Nature Reserve, 2009: 130; Shabalin, Bezborodov, 2012: 265; Bezborodov, 2014: 138).

\section{Distribution in Russia}

1. Moscow region

Material EXAmined: 1 spec. - label: "Moscow region, Ramensky district, Bykovo station, pine forest, first decade of August 1955", Rodnyanskaya (ZMMU).

Literature: Orekhovo-Zuyevo district (Nikitsky, 2009: 51); in mid 60 s of 20th century, south-east of the region (Nikitsky et al., 1996: 57).

\section{Vladimir region}

MAterial ExAmined: 1 spec. - label: "Vladimir region, Vladimirskiy uyezd, Lunevo village, on pine tree, 30.06.1908" A.N. Kazanskiy (ZMMU); 1 spec. label:"Vladimir region, on young pine shoots, in abundance, 1901" (ZIN); 1 spec. - label: "Lunevo village Vladimirsky uyezd" date illegible, end of 19th - beginning of 20th century [ 1895 or 1905 , approximately June] (ZMMU); 1 spec. Vladimir, label: "B. Sokanowski" (judging by labels this is an old specimen, of approximatelyw end 19th - first half, or rather third, of 20th century) (ZMMU).

LITERATURE: Lunevo village Vladimirskiy uyezd (in the vicinity of Vladinir on the river Klyazma) (currently - Vladimir) (Semenov, 1904: 114); Kurlovo, Ilino (Esterberg, 1929: 50); Meschera National Park (Semenov, 2010: 36).

\section{Ivanovo region}

MATERIAL EXAMINED: 1 spec. - Ivanovo region, Makarevsky district, first half of July, 1929, label: "B. Sokanovsky" (ZMMU); 1 spec. - label: "Pestyakovsky district, vicinity of Demidovo settlement, 28.06.1995", M.E. Smirnov.

LitERATURE: Klyazminskiy Nature Reserve, Yuzhsky district (Tikhomirov, 2010: 30); Balakhninskaya lowland, Yuzhsky district (Vasyushin, 2012: 103).

\section{Ryazan region}

LiTERATURE: Klepikovsky district, Spass-Klepiki, 1994, 1995, Laptevo, 1994; Kasimovsky district, Dankovo village, 1994, Gus-Zhelezny, 2009 (Red Book of Ryazan region, 2011: 228).

\section{Nizhny Novgorod region}

MATERIAl EXAMINED: 1 spec. - label: "Nizhny Novgorod region, Kudma river, 1/2.06.1892" (ZMMU); 1 spec. - label: “'Zaokskoe Lesnichestvo' of Vladimir region, 06.913”, (currently - Nizhny Novgorod region) (ZIN); 3 spec. - label: “Arzamas, 5, 19.07.1952, 24.06.1960”, B.S. Pavlov-Verevkin (SZM ISEA).

LiterATURE: Nizhny Novgorod city (Jacobson, 1900: 4; Medvedev, 1949: 109); Dzerzhinsky district, Seima station (Esterberg, 1957: 146).

\section{Republic of Mordovia}

Literature: Temnikov district, Tengushevo district (Ruchin, Egorov, 2015: 91).

\section{Kirov region}

Material EXAmined: 1 spec. - label: "Medvedsky pine forest, Vyatka region Barkhan. region, park, pine forest on burnt,
13.07.1923", Shernin coll., (ZIN); 1 spec. - label: "Kirov region, Orichi settlement, 11.07.1994”, G.I. Yuferev (ZMMU).

LITERATURE: Medvedsky pine forest, Korshik, Sovetsk, Kilmez (Shernin, 1974: 144); Kirov region (Yuferev, 1988: 58); Nolinsky district (Esterberg, 1957: 146).

\section{Udmurt Republic}

LiTERATURE: Krasnogorsk district (Dedukhin, 2003: 10), Kokman settlement (Dedukhin, 2003: 10); Seltinsky district (Dedukhin, 2003: 10); Yakshur-Bodinsky district (Dedukhin, 2003: 10); Udmurtia (Dedukhin et al., 2005: 302).

\section{Republic of Tatarstan}

LITERATURE: Kazan (Lindeman, 1871: 281).

\section{Orenburg region}

LITERATURE: Chkalov (currently - Orenburg) (Medvedev, 1949: 109).

\section{Republic of Bashkortostan}

Material ExAmined: 1 spec. - label: "Bashkiria, Arkhangelsky village council”, 06.[19]36 (ZMMU).

LITERATURE: Belaya river at the borders of Orskiy uyezd and Orenburg uyezd (currently - The Republic of Bashkortostan) (Jacobson, 1900: 4).

\section{Sverdlovsk region}

MATERIAL EXAMINED: 1 spec. - label: "Ural, Chusovaya river, Shaitansky factory, 08.07.1902" (currently - Pervouralsk) (ZIN).

\section{Chelyabinsk region}

MATERIAL EXAMINED: 1 spec. - label: "Ufimsky District, Zlatoustovsky uyezd, 11.07.1909”, E. Shirokokva (ZMMU); 1 spec. - Chelyabinsk region (ZIN); 6 spec. - label: "09.07.1999, Chelyabinsk region, 6,5 km North from Miass city, in the vicinity of Turgoyak lake $\left(55^{\circ} 10^{\prime} 42.26^{\prime \prime} \mathrm{N}, 60^{\circ}\right.$ 2'16.47'E), in twilight in young pine growth", Ivanov A.V. leg. (ZM IPAE).

\section{Kurgan region}

MATERIAL EXAMINED: 10 spec. - label: "Pritobolnyi district, vicin-

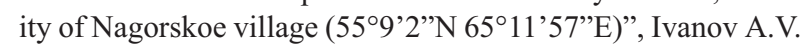
leg. (ZM IPAE); 1 spec. (dead) - label: "Shatrovsky district, Mostovka-2 village (56²'⒉28”N, 64²4’43.60”E), pine forest clearing”, Ivanov A.V. leg. (ZM IPAE); 2 spec. - label: "Pritobolny district, Utyatskoe village, 22.07.1997", A.V. Ivanov (SZM ISEA); 1 spec. - label: "Vargashinsky district, Shastovo, 25.06.1998", R.V. Filimonov; 2 spec. - label: "Ketovsky district, Temlyakovo village, 23.07.1997”, A.V. Ivanov (SZM ISEA).

\section{Yamalo-Nenets Autonomous District}

LiTERATURE: Krasnoselkupsky district (Sozinov, Sitnikov, 2005: 223).

\section{Tomsk region}

MATERIAL EXAMINED: 1 spec. - label: “Tomsk, 07.1949” (SZM ISEA).

LITERATURE: Inya river (Jacobson, 1900: 3).

\section{Novosibirsk region}

MATERIAL EXAmined: 1 spec. - Novosibirsk, 23.07.1968 (SZM ISEA); 2 spec. - label: "Ordynsky district: Krasnoyarsky kordon, 28.06.1962”, T. Martynenko (SZM ISEA); 1 spec. - label: 
"Zavyalovo, Novosibirskoye Reservoir, on pines on sand, 10.07.1973”, V.V. Dubatolov (SZM ISEA); 1 spec. - label: “Zavyalovo, 05.07.1966, Kharinova, V.K. Stroganova" (SZM ISEA).

\section{Kemerovo region}

MATERIAL EXAMINED: 1 spec. - label: "Kuznetsk (currently Novokuznetsk), 02.06.1901” (SZM ISEA); 1 spec. - label: "Novokuznetsky district, Kuznetsk Alatau, kordon Verkhnyaya Ters, bank of the Verkhnyaya Ters river, in the air, flying", A. Korshunov.

\section{Altai Krai}

Material EXAmined: 1 spec. - label: "Altai Krai, Yegoryevsky District, Lebyazhye" (ZMMU).

LiTERATURE: Barnaul (Lindeman, 1871: 281); Loktevsk (currently - Gornyak) (Lindeman, 1871: 281; Jacobson, 1900: 3); Tigirek village (Volynkin et al., 2011: 189).

\section{Altai Republic}

MATERIAL EXAMINED: 1 spec. - label: "Altai, Teletskoe lake" (ZIN); 1 spec. - label: "Turochaksky district, Artybash settlement, 23.07.2004", A.A. Safronov; 1 spec. - label: "Ust-Koksinsky district, Ust-Koksa, 04.08.1973” (Berman coll.) (SZM ISEA); 2 spec. - label: "7 km West from Katanda, 07.1983" (Dubatolov coll.) (SZM ISEA).

\section{Krasnoyarsk Krai}

MATERIAl EXAMINED: 1 spec. - label: "Krasnoyarsk, 24.06.[19]33" (ZMMU); 1 spec. - label: "Kryzhina ridge, $30 \mathrm{~km}$ East from Cheremchanki, Tarbat river, $\mathrm{h}=500-700 \mathrm{~m}$, spurce-birch forest, 1-5.07.2000" (A. and R. Dudko) (SZM ISEA).

LiTERATURE: Krasnoyarsk (Medvedev, 1949: 109).

\section{Tyva Republic}

Material ExAmined: 1 spec. - label: "Dzun-Khemchiksky District, Khondergej river, 23.07.1997" [TuvSU] (SZM ISEA); 1 spec. - label: "Tes-Khemsky district, $125 \mathrm{~km}$ West from Kyzyl, 06.07.1980” (Korotyaev) (SZM ISEA).

LiterATURE: Shagonar (Cherepanov, 1956: 69); Balgazinsky pine forest (Galkin, 1958: 3); Shagonarsky and Balgaziksky pine forest (Galkin, 1961: 1039, 1044); Khondergej river, Shagonar (Maryasova, 2016: 19); Ulug-Khemsky district (Kyzyl-oll, 2013: 84); Kyzyl city (Maryasova, 2016: 19); Tuva (Kyzyl-oll, 2003b: 83; Kyzyl-oll, 2004: 37); North West of Tuva (Kyzyloll, 2003a: 22); Tyva (Maryasova, 2016: 19).

\section{Irkutsk region}

Material EXAmined: 1 spec. - label: "vicinity of Irkutsk city, 30.07" [year not mentioned], V. Dorogostajsky (ZMMU); 2 spec. - label: "100 km West from Irkutsk, vicinity of Belorechensky settlement, 24.05.2003, in sand soils", N. Berlova; label: "Slyudyansky district, lower reaches of Khara-Murin river, 9, 10.07.1984" (Dubatolov) (SZM ISEA).

LitERATURE: Kirensk (Medvedev, 1949: 109); Kadinsky Nature Reserve (Shilenkov et al., 2014: 21); Mangutaj, Iya river (Berlov, Shilenkov, 1977: 94).

\section{Republic of Buryatia}

MATERIAl EXAMINED: 1 spec. - label: "Lake Baikal, Mishikha River, 10.08.2003”, D. Fominykh; label: "Severo-Baykalsky District: Uoyan settlement, 15.07.1969" (SZM ISEA); 4 spec. - label: “3 km NW from Romanovka village, 5312'8.99”N, $112^{\circ} 48^{\prime} 18.61$ 'E, in daytime on open sand beaches", Ivanov A.V. leg. (ZM IPAE).

LiterATURE: Kyakhta (Lindeman, 1871: 281); Vydrino, ZunMurino (Berlov, Shilenkov, 1977: 94).

\section{Zabaykalsky kray}

Material EXAmined: $1 \mathrm{spec}$ - - label: "Chita region, Menza river, Ust-Bulak, 28.07.1958, flying in twilight” (ZMMU).

LITERATURE: Nerchinsk (Lindeman, 1871: 281; Jacobson, 1900: 3).

\section{Amur region}

LiterATURE: Amur region (Lindeman, 1871: 281); Amur region (Jacobson, 1900: 3); Blagoveschensk district, Svobodny district, Belogorsk district, Arkharinsk district, Skovorodinsk district (Bezborodov, 2006: 308); Blagoveschensk (Bezborodov et al., 2011: 76); Amur region (Kalinina, 1989: 411; Bezborodov, 2016: 130).

\section{Khabarovsk Krai}

Literature: Bolshekhekhtsirsky State Nature Reserve (Bezborodov, Zinchenko, 2010: 45); Tuguro-Chumikansky district, Nikolaevsk district, Vyazemsky district (Bezborodov, 2014: 138); Bolshekhekhtsirsky State Nature Reserve (Bezborodov, 2009: 140); Khabarovsk Krai (Kalinina, 1989: 411; Bezborodov, 2016: 130).

\section{Jewish Autonomous Region}

Literature: Obluchensky district, Khingansk settlement, Birobidzhan district, Smidovich district, Leninskoe district, Oktyabr'sky district (Bezborodov, 2013a: 136); Jewish Autonomous Region (Bezborodov, 2016: 130).

\section{Primorsky Krai}

Material EXAmined: 1 spec. - label: "Lazovsky State Nature Reserve, vicinity of Kievka village, 07.08.1982"; 1 spec. label: "Lazovsky State Nature Reserve, 05.08.1982", L.V. Egorov; 4 spec. - label: "vicinity of Glazkovka settlement, 10.07.1982"; 1 spec. - label: "16.08.1982, light trap", L.V. Egorov; 3 spec. - label: "Ussuriysky District, $20 \mathrm{~km} \mathrm{NW}$ from Krounovka village, 25.06-5.07.2015”, S.A. Karpeev; 3 spec. label: "Ussuriysky District, vicinity of Kaymanovka village, in Umbelliferae", A. Korshunov; 2 spec. - label: "Ussuri district, $30 \mathrm{~km}$, SW from village, Krounovka ridge Death, $\mathrm{h}=252-$ 391m., 4337,26’N, 131²7,44'E, light trap”, A. Korshunov.

LiterATURE: Ussuriysky State Nature Reserve (Kuprin, Shabalin, 2012: 148); Ussuriysky State Nature Reserve (Bezborodov, Shabalin, 2013: 136); Lazovsky Nature Reserve (Insects of Lazovsky Nature Reserve, 2009: 130); Gusevsky mine, Kedrovka river, Gryaznaya river, Barabash settlement, Primorsky settlement, Narva river, Kedrovaya Pad State Nature Reserve (Bezborodov, 2013b: 83); Sikhote-Alinsky State Nature Reserve (Bezborodov, 2015: 70); SikhoteAlinsky State Nature Reserve (Degma, 1997: 7); Primorsky Krai (Litvinenko, 1960: 1406); Primorsky Krai (Kalinina, 1989: 411; Bezborodov, 2016: 130).

\section{Sakhalin region}

LiterAtURE: $7 \mathrm{~km}$ North from Kholmsk (Degma, 1997: 7); Tunaicha Lake, Gornozavodsk district, Okhinsk district, Chekhovsk district, Uglegorsky district, $6 \mathrm{~km}$ South from Shebunino, Novoaleksandrovsk, Dunino, Kazakevichi, Yuzhno-Sakhalinsk, Uglegorsk settlement, AleksandrovskSakhalinsky district, (all from: Shabalin, Bezborodov, 2012: 265); Sakhalin region (Kalinina, 1989: 411; Bezborodov, 
Shabalin, 2015: 321); Sakhalin (Jacobson, 1900: 3); Sakhalin (Bezborodov, 2016: 130).

\section{Discussion}

Within the Russian Federation this species is observed in 30 regions (Figure 1). However, its distribution in these areas is not even. Thus, the largest number of findings and the abundance of this species are typical for the Far East: Jewish Autonomous Region, Khabarovsk Krai, Primorsky Krai, Amur and Sakhalin regions. But in Khabarovsk Krai it is widespread only in the southern areas, in the north it reaches the Mayskiy mountain ridge (Bezborodov, 2014). In the Amur region it is quite abundant in the south-eastern part of the region (Bezborodov, 2006).

In Eastern Siberia M. holosericea is observed in the Zabaykalsky Krai, Krasnoyarsk Krai, Irkutsk region, Buryatia, but mostly in the southern parts of this vast geographic area. The most northern point here is the city of Kirensk (Medvedev, 1949).

In Western Siberia this species is recorded mainly in southeastern regions. Most findings come from the Republic of Tyva, Altai Krai, Altai Republic. Of special note is a report from YamaloNenets Autonomous District (Sozinov, Sitnikov, 2005). This is generally the most northern finding of this species in the entire range. There are some doubts about the correct determination of specimen, as authors give a Russian name as "meadow cockchafer = silky beetle (Rhombonyx holosericea)". On the other hand, there is an indication (Emtsev et al., 2012) of another scarab beetle Oryctes nasicornis (Linnaeus, 1758) massive finds within the district of Konda of Khanty-Mansiysk Autonomous District, located just $5 \square$ to the south of Krasnoselkup district of Yamalo-Nenets Autonomous District. Taking into account the steady trend towards the expansion of southern species habitats to the north, it is possible that similar situation is true for $M$. holosericea. We assume that species also occurs in Omsk and Tyumen regions and its detection here is a matter of time.

Data from the Urals (Sverdlovsk, Orenburg, Kurgan, Chelyabinsk regions, Bashkortostan, Udmurtia) is mostly based on century old collections. Current data from this extensive territory, which we have at our disposal, is true for Udmurtia and Kurgan region only.

Special attention should be payed to registration of this species at western border of the range - in the central regions of the European part of Russia. We have no doubt that this species inhabited these areas for a long time and remained an unobtrusive representative of Coleoptera fauna because of its small numbers. This is confirmed by the findings of species since the end of XIX - early XX centuries within the Vladimir, Ivanovo, Nizhny Novgorod, Kirov regions and some other regions of the European part of Russia. It is possible that in recent years the number of $M$. holosericea at the western border of the range is gradually increasing due to the general climate aridization. In South Russia species is not found (Shokhin, 2007).

In the Amur region the species was observed in sparse forests with an admixture of Pinus sylvestris on sandy soils, as well as in open spaces of Zeya River floodplains (Bezborodov, 2006). In the Jewish Autonomous region it is a common species, widespread throughout the territory (Bezborodov, 2014). According to observations in Khabarovsk Krai and Jewish Autonomous region it tends to floodplain cenoses (Bezborodov, 2013a, 2014). At the Ussuri Nature Reserve it is found in the shrub layer (Kuprin, Shabalin, 2012). The larvae live in the soil, feeding on roots of herbaceous plants (Shilenkov et al., 2014). According to labels and literary sources, beetles are active from June to August, in the evening or at night, often fly to the light.

\section{Conclusions}

Outside of Russia M. holosericea is common in Kazakhstan, Mongolia, in some northern provinces of China, on the Korean Peninsula and in Japan. Within the Russian Federation species is observed in 30 administrative areas (Far East, Eastern, Western and Southern Siberia, the Urals, Volga region and Central Russia). The largest number of findings and abundance of this of species are typical for the Far East: Jewish Autonomous region, Khabarovsk Krai, Primorsky Krai, Amur and Sakhalin regions. The northernmost point of findings for this species is Krasnoselkupsky region of Yamalo-Nenets Autonomous District.

In the western part of its range - Volga region and Central Russia - the species occurs sporadically. The number of findings here has recently increased. Key habitats are sparse pine forests (glades, roadsides, forest edges), floodplain cenoses. Our data on $M$. holosericea distribution will form the basis for monitoring of the range dynamics of this East Palaearctic species of beetles.

\section{References}

ABOOD F., MURPHY R.J., 2006 - World distribution of Minthea rugicollis (Coleoptera: Lyctidae). - J. Trop. Forest Sci. 18: 250254

BAYARTOGTOKH B., KIM J.I., BAE Y.J., 2012 - Lamellicorn beetles (Coleoptera: Scarabaeoidea) in Korea and Mongolia. Entomol. Res. 42: 211-218.

BERLOV E.YA., SHILENKOV V.G., 1977 - Lamellicorn beetles (Coleoptera, Lamellicornia) of South Baikal region. - Fauna and ecology of insects of eastern Siberia and the Far East. pp 87-101. [In Russian].

BEZBORODOV V.G., 2009 - New findings of lamellicorn beetles (Coleoptera, Scarabaeoidea) for the fauna of Bolshekhekhtsirskii reserve and Khabarovsky Krai. - Sixth Grodekovsky readings. Vol. 4. Habarovsk: Khabarovsk: Khabarovsk regional museum of N.I. Grodekov. pp. 138-141. [In Russian].

BEZBORODOV V.G., 2006 - A Review of cockchafers (Coleoptera, Scarabaeidae) faunae of the Amur Region. Subfamilies: Rutelinae, Sericinae, Rhizotroginae, Hopliinae. Euroas. Entomol. J. 5: 307-312. [In Russian].

BEZBORODOV V.G., 2013a - Annotated checklist of the Lamellicorn beetles (Coleoptera, Scarabaeoidea) in the fauna of Jewish Autonomous Region (Russia). - Amur. Zool. J. 2: 125-146. [In Russian].

BEZBORODOV V.G., 2013b - Lamellicorn beetles (Coleoptera, Scarabaeoidea) of Nature Reserve "Kedrovaya Pad" and adjacent territories (Primorskiy Krai, Russia). - The social and economic and humanitarian magazine of Krasnoyarsk SAU 4: 7688. [In Russian].

BEZBORODOV V.G., 2014 - Annotated checklist of lamellicorn beetles in the fauna (Coleoptera, Scarabaeoidea) of the Khabarovsk Krai (Russia). - Amur. Zool. J. 6: 125-146. [In Russian].

BEZBORODOV V.G., 2015 - Lamellicorn beetles (Coleoptera, Scarabaeoidea) of the Sikhote-Alin Nature Reserve and adjacent territories (Primorsky Krai, Russia). - Herald of Tver State 
University. Series: Biology and Ecology. pp 63-74. [In Russian].

BEZBORODOV V.G., 2016 - Annotated checklist of lamellicorn beetles in the fauna (Coleoptera, Scarabaeoidea) of Far East of Russia. - Amur. Zool. J. 8: 110-153. [In Russian].

BEZBORODOV V.G., AISTOVA E.V., ROGATNYKH D.YU., 2011 - Evaluation of the potential harm of cockchafers larvae (Coleoptera, Scarabaeidae: Rutelinae, Rhizotroginae, Sericinae) on the collection sites of the Amur branch of Botanical Garden-Institute FEB RAS. - Plant Prot. News 3: 75-77. [In Russian].

BEZBORODOV V.G., SHABALIN S.A., 2013 - A comparative analysis of lamellicorn beetle local fauna structures (Coleoptera, Scarabaeoidea) of Ussuriisky Nature Reserve and adjacent territories of Primorsky Krai, Russia. - Euroasian Entomol. J. 12: 132-138. [In Russian].

BEZBORODOV V.G., SHABALIN S.A., 2015 - Lamellicorn beetles (Coleoptera: Scarabaeoidea) of Sakhalin Island: taxonomical structure, fauna, ecology and zoogeography. - Caucas. Entomol. Bull. 11: 317-25. [In Russian].

BEZBORODOV V.G., ZINCHENKO V.K., 2010 - Lammelicorn beetles (Coleoptera, Scarabaeoidea) of Bolshekhekhtsirsky Nature Reserve and adjacent territories (Khabarovsk Krai). Amur. Zool. J. 2: 41-49. [In Russian].

CHEREPANOV A.I., 1956 - Insects of Tuva Autonomous Region. Proceedings of the Biological Institute of the USSR Academy of Sciences. Issue 1. Zoological. P. 35-77. [In Russian].

DEDUKHIN S.V., 2003 - Lamellicorn beetles (Coleoptera, Scarabaeoidea: Trogidae, Scarabaeidae, Lucanidae) of Udmurt Republic. - Bull. Moscow Soc. Natural. Biol. series. 108: 3-13.

DEDYUKHIN S.V., NIKITSKY N.B., SEMENOV V.B., 2005 Checklist of beetles (Insecta, Coleoptera) of Udmurtia. Euras. Entomol. J. 4: 293-315. [In Russian].

DEGMA P., 1997 - Results of the expedition "Ussuri '95": Scarabaeoidea (Coleoptera). Far Eastern Entomologist 49: 6-8.

EMTSEV A.A., BERNIKOV K.A., AKOPYAN E.K., 2012 About the expansion of the areas' borders of some animals' species in the northern part of Western Siberia. - Mir Nauki, Kul'tury, Obrazovaniya 6: 471-477. [In Russian].

ESTERBERG L.K., 1929 - To the knowledge of Coleóptera of the Vladimirskiy Region. - Proceedings of the Vladimir Provincial Research Society for the Study of local region. Natural History Collection, ed. I.V. Malitsky et al. Vladimir. pp. 42-51. [In Russian].

ESTERBERG L.K., 1957 - Interesting beetles (Coleoptera) in Gorkovskiy and Kirovskiy regions. - Entomol. Rev. 36: 142147. [In Russian].

FABRICIUS J.C., 1787 - Mantissa insectorum sistems eorum species nuper detectus adiectis characteribus genericis, differentiis specificis emendationibus, descriptionibus. Tom I. Hafniae: Christ. Gottl. Proft, $x x+348$ p.

FAUNA EUROPAEA - All European animal species online (http://www.fauna-eu.org). 2017.

GALKIN G.I., 1958 - Mongolian cockchafer (Brahmina agnella Fald.) in the Tuva Autonomous Region. - Krasnoyarsk. 44 p. [In Russian].

GALKIN G.I., 1961 - Biology and ecology of Siberian green cockchafer (Rhombonyx holosericea F.) in Tuva. - Zool. J. 40: 1039-1045.

HU HONGYING, HUANG RENXIN (eds.), 2013 - Colored pictorial handbook of insects in Xinjiang. Urumqi: Xinjiang University press. 300 p. [in Chinese].

HUA L., 2002 - Superfamilia Scarabaeoidea. List of Chinese insects. Zhongshan (Sun Yatsen) - University Press. Guangzhou. Vol. 2. pp 152-188.

JAKOBSON G., 1900 - Interesting location of certain beetles. Year-book of a zoological museum of an imperial academy of sciences. Vol. 5. Small notes. pp 1-9. [In Russian].

KALININA O.I., 1989 - Subfamily Rutelinae. Key to the Insects of the Far East of the USSR. Vol. III Coleoptera or Beetles. Part 1. Leningrad - Nauka. pp 409-416. [In Russian].

KIM S., JUNG M., KIM H., SHIN J., LIM J., KIM T., LEE J., 2006 - Insect fauna of adjacent areas of DMZ in Korea. J. Ecol. Fiel Biol. 29: 125-141.

KRAJČÍK M., 2008 - Checklist of Scarabaeoidea of the world. 2. Rutelinae (Coleoptera: Scarabaeidae: Rutelinae). - pp 1-139.

KUPRIN A.V., SHABALIN S.A., 2012 - Vertical stratification of beetles (Coleoptera) in lowland forests of Ussurisky Nature Reserve. - Adings in memory of Alexei Ivanovich Kurentsov. Issue XXIII. pp 145-156. [In Russian].

KURZAWA J., 2012 - Distribution of Rhaphuma gracilipes (Faldermann, 1835) (Coleoptera: Cerambycidae) in Europe. Acta Entomol. Siles. 20; 65-70.

KYZYL-OOL V.A., 2003a - Functional significance of Coprophagic beetles (Coleoptera, Scarabaeidae) in terrestrial ecosystems of the Republic of Tyva. - Ecol. Environ. Issues 20-21. [In Russian].

KYZYL-OOL V.A., 2003b - Fauna of coprophagic beetles (Coleoptera, Scarabaeidae) in landscapes of Tuva. - Ecology of South Siberia and adjacent territories. Krasnoyarsk. Vol. 1. P. 83-84. [In Russian].

KYZYL-OOL V.A., 2004 - Lamellicorn beetles in ecosystems of Tuva (Coleoptera, Scarabaeoidae). - Ecol. Environ. Issues. P. 28-29. [In Russian].

KYZYL-OOL V.A., 2013 - Cockchafers (Coleoptera, Scarabaeidae) of Tyva Republic. Biodiversity, environmental problems of the Altai Mountains and adjacent regions: past, present, future. - Gorno-Altaysk. P. 83-85. [In Russian].

LIMBOURG P., 2014 - Contribution to the knowledge of Afrotropical Rutelinae III (Coleoptera, Scarabaeoidea, Melolonthidae). - Belgian J Entomol. 17: 1-33.

LINDEMAN K., 1871 - Review of geographical distribution beetles of Russian empire. - Proc. Russian Entomol. Soc. 6: 41336. [In Russian].

LITVINENKO N.M., 1960 - To the ecology of Dollarbird (Eurystomus orientalis abundus Ripley). - Zool. J. 39: 14031407. [In Russian].

MARYASOVA V.A., 2016 - Materials to the fauna of lamellicorn beetles (Coleoptera, Scarabaeoidea) in Tyva. Vestnik Magistratury. 2: 17-21. [In Russian].

MATSUMURA S., 1911 - Beitrag zur Insekten-Fauna von Sachalin. - J Coll. Agricult. 4: 1-145.

MEDVEDEV S.I., 1949 - Scarab beetles (Scarabaeidae). Subfamily Rutelinae (Grain beetles and related groups). Fauna of the USSR. Coleoptera. Vol. 10. Issue. 3. New Series, No. 46, Moscow-Leningrad: Publishing House of the USSR Academy of Sciences, 372 p. [In Russian].

NIKITSKY N.B., 2009 - New and interesting finds of xylophilous and some other beetles (Coleoptera) in the Moscow Region and in Moscow. - Bull. Moscow Soc. Natur. Biol. series 114: 50-58. [In Russian].

NIKITSKY N.B., OSIPOV I.N., CHEMERIS M.V., SEMENOV V.B., GUSAKOV A.A., 1996 - Beetles xylobionts, mycetobionts and scarabaeids of Prioksko-Terrasny Biosphere Reserve (with fauna review of these groups in Moscow region). - Moscow: Moscow University Publishing House. [In Russian]. 
NIKOLAJEV G.V., 1987 - Scarab beetles (Coleoptera, Scarabaeoidea) of Kazakhstan and Middle Asia. - Alma-Ata: Nauka. [In Russian].

NIKOLAJEV G.V., PONTSAGDULAM J., 1984 - Scarab beetles (Coleoptera, Scarabaeoidea) of the Mongolian People's Republic. Insects of Mongolia. Leningrad: Nauka. pp. 90-294. [In Russian].

PARK S., CHO Y., KIM Y., HAN Y., LIM H., PARK S., HONG E., 2010 - Insect Fauna of Is. Boleum-do (Prov. Gyeonggi-do), Korea. - J. Korean Nat. 3: 15-24.

RYAZAN N.P., 2011 - Red Book of Ryazan Region. "Globus Gubrnii”. [In Russian].

RUCHIN A.B., EGOROV L.V., 2015 - Beetle (Coleoptera) species of the Republic of Mordovia recommended for protection (main list of protected taxa). - Proc. Mordovia State Nat. Res. 15: 70-104. [In Russian].

RUCHIN A.B., KURMAEVA D.K., 2010 - On rare insects of Mordovia included in the Red Book of the Russian Federation. - Entomol. Rev. 90: 712-717.

RUSSIAN ACADEMY OF SCIENCES. Insects of Lazovsky Nature Reserve. Vladivostok. - Dalnauka, 2009. 464 p. [In Russian].

SARKAR, S.K., SAHA, S., RAYCHAUDHURI, D. 2016 - On the Mimela Kirby, 1823 (Rutelinae: Scarabaeidae) of Buxa Tiger Reserve (a forest under biodiversity hot spot zone), - Dooars, West Bengal, India. World Scientific News. 50: 95-105.

SEKERKA L., 2007 - Detailed distribution of Cassida sanguinosa and C. leucanthemi (Coleoptera: Chrysomelidae: Cassidinae: Cassidini). - Acta Entomol. Musei Nationalis Pragae. 47: 203-209.

SEMENOV A., 1904 - Notes on Coleoptera from the European Russia and Caucasus. - Entomol. Rev. 6: 111-116. [In Russian].

SEMENOV V.B., 2010 - An annotated checklist of beetles (Coleoptera) of Central Meshchera. Addition 1. - Eversmannia. 23-24: 26-39. [In Russian].

SHABALIN S.A., 2011 - Distribution of the Scarab beetles (Coleoptera, Scarabaeoidea) in regions Far East of Russia. Key to the insects of Russian Far East. Additional volume. Analysis of the fauna and general index of the names. - Vladivostok: Dalnauka Publishing House. pp 65-80. [In Russian].

SHABALIN S.A., BEZBORODOV V.G., 2012 - Lamellicorn beetles (Coleoptera, Scarabaeoidea) of the Sakhalin Region. Flora and fauna of the Islands of the North-Western Pacific ocean: Materials of International Kuril and International Sakhalin projects). - Vladivostok: Dalnauka Publishing House. pp 247287. [In Russian].
SHERNIN A.I., 1974 - Chapter 7. Orders Coleoptera, Strepsiptera. - Fauna of the Kirov Region (2). Kirov. pp 111-227. [In Russian].

SHILENKOV V.G., PANKRATOV A.A., 2014 - Insect fauna of Kadinsky reserve. Preliminary notes. - Baikal Zool. J. 1: 1825. [In Russian].

SHOKHIN I.V., 2007 - Contribution to the fauna of lamellicorn beetles (Coleoptera, Scarabaeoidea) of Southern Russia. Caucas. Entomol. Bull. 3: 105-185. [In Russian].

SOZINOV D.I., SITNIKOV P.S., 2005 - Lamelicorn beatles (Coleoptera, Scarabaeidae) of Tyumen region. Slovtsovskie readings-2005. Tyumen: - Tyumen State University Press. P. 222-224. In Russian.

STEBNICKA Z., 1980 - Scarabaeoidea (Coleoptera) of the Democratic People's Republic of Korea. - Acta zoologica cracoviensia. Vol. 24. No 5. P. 191-298.

TIKHOMIROV A.M., 2012. Annotated checklist of Ivanovo region insect species that are not included in the Red Book, but require special attention to their status in the environment. Rare animals and fungi: Materials on keeping of the Red Book of Ivanovo region. Ivanovo: PresSto. pp 29-34. [In Russian].

UENO S., KUROSAWA Y., MASATAKA S., 1989 - Superfamilia Scarabaeoidea. - The Coleoptera of Japan in Color. Vol. 2. Tsurumi, Tsurumi-ku. Osaca. pp 329-419.

VASYUSHIN I.N., 2012. Overview of Coleoptera fauna of the northern part of the Balakhna lowland. - Specially protected natural territories and objects of the Vladimir region and adjacent regions. Vladimir. pp 103-106. [In Russian].

VOLYNKIN A.V., TRILIKAUSKAS L.A., BAGIROV R.T.O., BURMISTROV M.V., BYVALTSEV A.M., VASILENKO S.V., VISHNEVSKAYA M.S., DANILOV YU.N., DUDKO A.YU., DUDKO R.YU., KNYSHOV A.A., KOSOVA O.V., KOSTROV D.V., KRUGOVA T.M., KUZNETSOVA R.O., KUZMENKIN D.V., LEGALOV A.A., LVOVSKIJ A.L., NAMYATOVA A.A., NEDOSHIVINA S.V., 2011 Invertabrate animals of the Tigirekski Reserve. Annotated checklist of species. - Proceeding of the Tigirek State Natural Reserve, pp 165-226. [In Russian].

YUFEREV G.I., 1988 - Rare beetles of Kirov region and their protection issues - Animal Protection of Middle Volga. Kuibyshev. pp 56-60. [In Russian].

ZORN C., BEZDĚK A., 2016 - Subfamily Rutelinae W.S. Macleay, 1819. Catalogue of Palaearctic Coleoptera. Vol. 3. Revised and updated version. Scarabaeoidea - Scirtoidea Dascilloidea - Buprestoidea - Byrrhoidea. Löbl I. \& Löbl D. (eds.). Leiden-Boston: Brill. pp 317-358. 